\title{
ANALISIS SIFAT KIMIA GAMBUT PASCA KEBAKARAN DENGAN BERBAGAI UPAYA PEMULIHAN HUTAN DI KAWASAN HUTAN DENGAN TUJUAN KHUSUS (KHDTK) TUMBANG NUSA, KALIMANTAN TENGAH
}

\author{
Analysis of Peat Chemical Properties After Land Fire with Various \\ Forest Recovery Efforts in Forest Area for Special Purpose (KHDTK) \\ Tumbang Nusa, Central Kalimantan
}

\author{
Fytria Kurniasari $^{1^{*}}$, Syahrul Kurniawan ${ }^{1}$, Lenny Sri Nopriani ${ }^{1}$, Dony Rachmanadi ${ }^{2}$ \\ 1 Jurusan Tanah Fakultas Pertanian Universitas Brawijaya, Jl. Veteran no. 1 Kota Malang, 65145 \\ ${ }^{2}$ Balai Penelitian dan Pengembangan Lingkungan Hidup dan Kehutanan, Banjarbaru, JL. Ahmad Yani, KM. \\ 28, Landasan Ulin Kota Banjarbaru, Kalimantan Selatan 70721 \\ *Penulis korespondensi: fytriaks@gmail.com
}

\begin{abstract}
Peat land has an important role, function, and benefit for human life, biodiversity, and global climate. The peat swamp forest in Central Kalimantan was devastated to a very large extent, which addresses the restoration of peat swamp forests, has changed the characteristics of peat which contain physical, chemical, and biological characteristics. Peat recovery efforts carried out at the KHDTK Tumbang Nusa consist of natural succession and revegetation. The study aimed to analyze the chemical properties of peat soils in different types of post-fire forest protection and to assess the spatial variability of peat chemical properties in Forest Areas for Special Purposes (KHDTK) Tumbang Nusa, Desa Tumbang Nusa, Jabiren Raya District, Pulang Pisau Regency. The research plot consisted of forest restoration efforts, namely secondary forest, revegetation, and natural regeneration. Variable measured consisted of $\mathrm{pH}$, total organic $\mathrm{C}, \mathrm{CEC}, \mathrm{N}, \mathrm{P}, \mathrm{K}$, exchangeable $\mathrm{K}, \mathrm{Na}, \mathrm{Ca}, \mathrm{Mg}$, as well as ash content and water content. The results showed that secondary forest treatment was the best peat swamp forest restoration technique. Spatial variability sub-plots and sample points did not significantly affect the differences in chemical properties of the peat, but the differences in chemical properties of peat is the peat swamp forest was determined by restoration technique.
\end{abstract}

Keywords: natural regeneration, peat, revegetation, secondary forest, spatial compatibility

\section{Pendahuluan}

Gambut memiliki peran, fungsi, dan manfaat yang sangat penting bagi kehidupan manusia, keanekaragaman hayati, dan iklim global. Hutan rawa gambut yang ada di Kalimantan khususnya Kalimantan Tengah mengalami kerusakan yang sangat besar seiring dengan berjalannya aktivitas pembukaan lahan gambut 1 juta hektar untuk lahan sawah yang dikenal dengan Proyek Pembukaan Lahan Gambut sejuta hektar (PPLG). Proyek ini diberhentikan tahun 1998 karena dinilai merusak ekosistem karena mengakibatkan terjadinya kebakaran hutan rawa gambut dalam jumlah masal (Boehm dan Siegert, 2001). Luas lahan terbakar di Kalimantan Tengah tahun 2015 seluas 583,833 ha dari luas lahan gambut sebelum kebakaran pada tahun 2011 seluas 2.659.000 ha (Kementerian Lingkungan Hidup dan Kehutanan, 2015). Kebakaran yang terjadi mengakibatkan perubahan karakteristik gambut yang meliputi sifat fisika, kimia, dan biologi. Secara alamiah gambut memiliki tingkat kesuburan rendah karena rendahnya kandungan unsur hara dan mengandung beragam asam- 
asam organik yang sebagian bersifat racun bagi tanaman. Namun demikian asam-asam tersebut merupakan bagian aktif dari tanah, yang menentukan kemampuan gambut untuk menahan sifat kimia gambut (Hartatik et al., 2011).

Upaya pemulihan fungsi ekosistem gambut dapat dilakukan melalui suksesi alami, rehabilitasi ekosistem, restorasi ekosistem dan cara lain sesuai pengetahuan dan teknologi (Marlina, 2017). Upaya pemulihan gambut yang dilakukan di lokasi penelitian berupa suksesi alami yaitu kawasan regenerasi alami dan rehabilitasi yaitu revegetasi. Upaya ini akan menghasilkan komponen vegetasi yang berbeda-beda dan akan menunjukkan pemodelan keadaan suatu lahan dalam mencapai kondisi yang diinginkan dengan melihat salah satu faktor yang penting yaitu sifat kimia gambut dalam penelitian ini berupa $\mathrm{pH}\left(\mathrm{KCl}\right.$ dan $\left.\mathrm{H}_{2} \mathrm{O}\right)$, C-organik, KTK, N, P, K, basa dapat ditukar (K, $\mathrm{Ca}, \mathrm{Na}, \mathrm{Mg}$ ) serta kadar abu dan kadar air. Pengukuran sifat kimia gambut dalam menilai tingkat kematangan menunjukkan keragaman yang sangat tinggi. Hal ini dipengaruhi oleh transformasi bahan kimia yang ada di lahan gambut (Kurnain et al., 2001) sehingga penting untuk menganalisis keragaman lokasi (titik sampel dan sub plot) di plot pengamatan. Penelitian ini bertujuan untuk mengetahui sifat kimia gambut pada perbedaan upaya pengelolaan upaya pemulihan hutan pasca kebakaran dan dapat menganalisis pengaruh keragaman lokasi (titik sampel dan sub plot) terhadap sifat kimia gambut di Kawasan Hutan Dengan Tujuan Khusus (KHDTK) Tumbang Nusa, Desa Tumbang Nusa, Kecamatan Jabiren Raya, Kabupaten Pulang Pisau.

\section{Bahan dan Metode}

Penelitian dilaksanakan di Kawasan Hutan Dengan Tujuan Khusus (KHDTK) Tumbang Nusa, Desa Tumbang Nusa, Kecamatan Jabiren Raya, Kabupaten Pulang Pisau, Kalimantan Tengah pada bulan November 2019 hingga Februari 2020. Analisis laboratorium dilakukan di Laboratorium Balai Penelitian Tanaman Pangan Lahan Rawa di Banjarbaru, Kalimantan Selatan. Pengamatan dilakukan dengan menggunakan metode survei di tiga upaya pemulihan hutan yakni hutan sekunder (HS), revegetasi (RB) dan regenerasi alami (RA).

\section{Persiapan dan pengambilan sampel tanah}

Persiapan penelitian meliputi pembuatan plot penelitian dengan cara pengolahan data citra menggunakan aplikasi ArcGIS. Keterangan titik pada gambar menunjukkan titik merah merupakan areal semak belukar sedang yang berubah menjadi areal revegetasi, titik kuning merupakan areal semak belukar yakni areal regenerasi alami dan titik hitam merupakan areal hutan (Gambar 1).

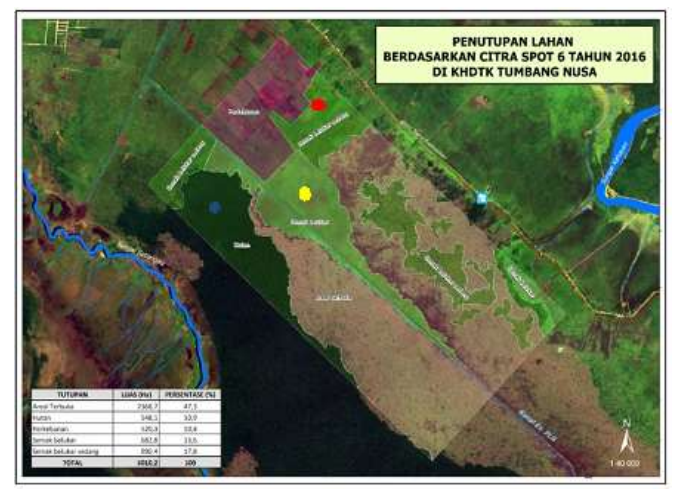

Gambar 1. Citra spot 6 KHDTK Tumbang Nusa.

Pengamatan dilakukan dalam petak pewakil disetiap kawasan dengan ukuran $400 \mathrm{~m}$ x $50 \mathrm{~m}$ pada seluruh titik pengamatan (Gambar 2). Sampel diambil pada tiap titik pengamatan dengan kedalaman $0-50 \mathrm{~cm}$ menggunakan parang (dibuat kotak dengan ukuran $50 \mathrm{~cm}$ x 50 $\mathrm{cm}$ ) kemudian tiap titik pengamatan pada plot yang sama dicampur rata (komposit). Secara keseluruhan, jumlah sampel yang diambil sebanyak 3 (main plot) x 5 (titik sampel/pengamatan) x 4 (sub plot) $=60$ sampel.

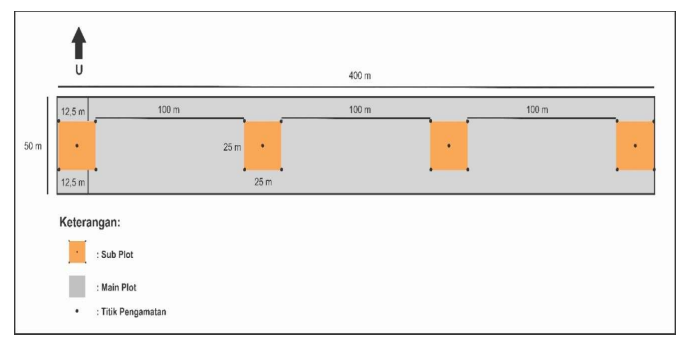

Gambar 2. Desain plot pengamatan. 


\section{Jurnal Tanah dan Sumberdaya Lahan Vol 8 No 1: 221-230, 2021}

e-ISSN:2549-9793, doi: 10.21776/ub.jts1.2021.008.1.25

\section{Analisis laboratorium dan data}

Analisis dilakukan dengan mengkompositkan sampel pada jenis tanah dan kedalaman yang sama pada plot yang sama. Analisis laboratorium meliputi pengukuran $\mathrm{pH} \mathrm{KCl}$ dan $\mathrm{H}_{2} \mathrm{O}(\mathrm{pH}$ meter), C-organik (muffle), KTK (destilasi), $\mathrm{N}$ (kjeldahl), P total (ekstrak $\mathrm{HCl} 25 \%, \mathrm{P}$ tersedia(olsen), $\mathrm{K}$ (ekstrak $\mathrm{HCl} 25 \%$ ), basa dapat ditukar $\mathrm{K}, \mathrm{Ca}, \mathrm{Na}, \mathrm{Mg}\left(\mathrm{NH}_{4} \mathrm{OAc} 1 \mathrm{M}\right)$, serta kadar abu (pengabuan) dan kadar air (gravimetrik). Pengolahan data dilakukan dengan menggunakan $\mathrm{R}$ program statistik. Analisis keragaman (ANOVA) dilakukan untuk mengetahui perbedaan sifat kimia tanah dari berbagai upaya pemulihan hutan rawa gambut dengan uji Linear Mixed Effects Models. Apabila terdapat perbedaan yang nyata $(\mathrm{p}<0,05)$, maka dilakukan uji lanjut BNT taraf 5\% sedangkan untuk melihat keragaman sifat kimia tanah pada variabel efek-acak (random effect) yaitu titik sampel dan sub plot menggunakan Variance Component Analysis.

\section{Hasil dan Pembahasan}

\section{Lokasi lahan}

Penelitian ini dilakukan pada tiga lokasi yakni hutan sekunder, revegetasi dan regenerasi alami yang masuk ke dalam Kawasan Hutan Dengan Tujuan Khusus (KHDTK) Tumbang Nusa. Secara administratif berada dalam wilayah Desa Tumbang Nusa, Kecamatan Jabiren Raya, Kabupaten Pulang Pisau, Provinsi Kalimantan Tengah. Secara geografis terletak pada

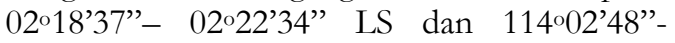
114006'46" BT dengan luas 5.000 ha.

\section{Kemasaman tanah $(p H)$}

Kemasaman tanah $(\mathrm{pH})$ dapat memengaruhi ketersediaan hara tanah dan dapat menjadi faktor yang berhubungan dengan kualitas tanah dan faktor pembatas pertumbuhan dan produksi tanaman (Sudaryono, 2009). Kemasaman gambut menjadi salah satu kendala pada sifat gambut, karena hidrolisis asam-asam organik dan kondisi drainase yang buruk (Agus et al., 2016). Secara keseluruhan, nilai $\mathrm{pH}$ pada seluruh upaya pemulihan hutan rawa gambut memiliki kriteria sangat masam. Menurut Miller dan Donahue (1990) gambut di Indonesia sebagian besar bereaksi masam hingga sangat masam dengan $\mathrm{pH}<4.0$. Tingkat kemasaman tanah berhubungan erat dengan kandungan asam-asam organik, yaitu asam humat dan asam fulvat. Perlakuan regenerasi alami berbeda nyata terhadap $\mathrm{pH} \mathrm{H}_{2} \mathrm{O}$, namun tidak berbeda nyata terhadap $\mathrm{pH} \mathrm{KCl}$ dengan $\mathrm{pH}$ sangat masam (terendah) dimiliki oleh regenerasi alami dengan $\mathrm{pH} \mathrm{H}_{2} \mathrm{O}$ sebesar 2,69 dan $\mathrm{pH} \mathrm{KCl}$ sebesar 1,51 sedangkan $\mathrm{pH}$ tertinggi dimiliki oleh hutan sekunder (Tabel 1). Hal ini karena proses dekomposisi yang baru berlangsung sehingga gambut dikatakan tidak cukup matang akibat kebakaran hutan tahun 2015. Gambut yang mengalami perombakan lebih lanjut (matang) memiliki $\mathrm{pH}$ nisbi yang lebih tinggi. Gambut yang tersusun dari bahan gambut yang belum atau kurang matang, nisbi belum terurai dan mengandung asam-asam organik dengan konsentrasi yang lebih tinggi sehingga nisbi masam (Kurnain et al., 2001).

\section{Karbon organik (C-organik)}

C-organik merupakan bagian fungsional dari bahan organik tanah yang memiliki fungsi dan peran dalam menentukan kesuburan dan produktivitas tanah. Bahan organik merupakan sumber utama unsur hara esensial yang dihasilkan dari proses dekomposisi dan mineralisasi bahan organik (Nurida dan Jubaedah, 2014).

Secara keseluruhan, nilai karbon organik pada seluruh upaya pemulihan hutan rawa gambut memiliki kriteria sangat tinggi. Hasil kriteria ini sama dengan penelitian yang dilakukan Setiadi et al., (2016) bahwa kandungan C-total di Desa Tumbang Nusa tergolong sangat tinggi. Hal ini disebabkan oleh tingginya bahan organik yang berasal dari sisa pembakaran berupa hemiselulosa, selulosa dan lignin yang menjadi senyawa karbon dioksida $\left(\mathrm{CO}_{2}\right)$ yang dilepas dalam bentuk gas dan karbonat $\left(\mathrm{CO}_{3}\right)$ sehingga akan terakumulasi pada abu menyebabkan karbon di tanah meningkat.

Perlakuan regenerasi alami berbeda nyata terhadap C-organik dengan nilai tertinggi terdapat pada hutan sekunder sebesar 54,30\% sedangkan nilai terendah terdapat pada regenerasi alami sebesar 52,09 \% (Tabel 1). Hal ini diduga karena masukan bahan organik pada hutan sekunder lebih banyak dibandingkan 


\section{Jurnal Tanah dan Sumberdaya Lahan Vol 8 No 1: 221-230, 2021 e-ISSN:2549-9793, doi: 10.21776/ub.jts1.2021.008.1.25}

dengan revegetasi dan regenerasi alami sehingga bahan yang akan terdekomposisi tersedia dalam jumlah banyak. Aristio et al. (2017) melaporkan bahwa semakin banyak masukan atau penambahan bahan organik pada gambut akan meningkatkan kandungan asam-asam organik yang ada sehingga akan terjadi peningkatan nilai C-organik pada tanah tersebut.

Faktor lain yang mempengaruhi dekomposisi bahan organik yaitu faktor lingkungan berupa pH (Sulistiyanto et al., 2005). Secara umum laju dekomposisi lebih lambat terjadi pada tanah dengan $\mathrm{pH}$ rendah dibandingkan pada $\mathrm{pH}$ netral. Hal ini diperkuat dengan hasil penelitian yang telah dilakukan bahwa $\mathrm{pH}$ terendah terdapat pada renegerasi alami yang juga memiliki kandungan C-organik terendah pula.

\section{Kapasitas Tukar Kation (KTK)}

Kapasitas tukar kation (KTK) merupakan kemampuan tanah dalam menjerap dan melepaskan kation yang dinyatakan sebagai total kation yang dapat dipertukarkan (Winarso, 2005). Secara keseluruhan, nilai KTK pada seluruh upaya pemulihan hutan rawa gambut memiliki kriteria sangat tinggi. Tingginya KTK pada gambut disebabkan oleh tingginya kandungan bahan organik tanah yang tersusun oleh fraksi lignin dan senyawa humat. Semakin tinggi fraksi lignin dan senyawa humat pada gambut, maka nilai KTK juga akan semakin tinggi (Setiawan, 1991). Perlakuan regenerasi alami berbeda nyata terhadap KTK dengan nilai tertinggi terdapat pada hutan sekunder sebesar $143,74 \mathrm{cmol}(+) \mathrm{kg}^{-1}$ sedangkan nilai terendah terdapat pada regenerasi alami sebesar 116,78 cmol(+) $\mathrm{kg}^{-1}$ (Tabel 1). Nilai KTK dipengaruhi oleh $\mathrm{pH}$ tanah dan ketersediaan bahan organik, yakni peningkatan $\mathrm{pH}$ dan bahan organik di tanah akan meningkatkan nilai KTK (Sembiring et al., 2015; Rusdiana dan Lubis, 2012). Kandungan bahan organik yang tinggi pada hutan sekunder sebagai dampak dari tingginya keanekaragaman dan populasi vegetasinya meningkatkan jumlah gugus fungsional pada bahan organik. Muatan negatif dari bahan organik tersebut mampu mempertukarkan kation dalam tanah sehingga mampu meningkatkan K'TK (Sembiring et al., 2015).

Tabel 1. Derajat kemasaman, C-organik dan kapasitas tukar kation pada berbagai upaya pemulihan hutan.

\begin{tabular}{|c|c|c|c|c|c|c|c|c|}
\hline $\mathbf{P H}$ & $\mathrm{pH} \mathrm{H_{2 } \mathrm { O }}$ & $\mathrm{Kr}$ & $\mathrm{pH} \mathrm{KCl}$ & $\mathrm{Kr}$ & $\begin{array}{l}\text { C-org } \\
(\%)\end{array}$ & $\mathrm{Kr}$ & $\begin{array}{c}\text { KTK } \\
\left(\mathrm{cmol}(+) \mathrm{kg}^{-1}\right)\end{array}$ & $\mathrm{Kr}$ \\
\hline HS & $2,75 \mathrm{a}$ & SM & 1,52 & SM & $54,30 \mathrm{a}$ & ST & $143,74 \mathrm{a}$ & ST \\
\hline $\mathrm{RB}$ & $2,75 \mathrm{a}$ & SM & 1,52 & SM & $53,95 \mathrm{a}$ & ST & $138,81 \mathrm{a}$ & ST \\
\hline RA & $2,69 \mathrm{~b}$ & SM & 1,51 & SM & $52,09 \mathrm{~b}$ & ST & $116,78 \mathrm{~b}$ & ST \\
\hline$p=$ & $<, 0001^{*}$ & & 0,35 tn & & $0,0041 *$ & & $<, 0001 *$ & \\
\hline
\end{tabular}

Keterangan: Angka yang diikuti dengan huruf yang beda pada kolom yang sama menyatakan beda nyata uji BNT 5\%.*(nyata); tn (tidak nyata). ST: sangat tinggi; SM: sangat masam; PH: Pemulihan Hutan; HS: Hutan Sekunder; RB: Revegetasi; RA: Regenerasi alami, $\mathrm{Kr}=$ kriteria.

\section{Nitrogen (N)}

Unsur hara $\mathrm{N}$ memiliki peranan yang sangat penting dalam pertumbuhan tanaman terutama fase vegetatif (Mindawati et al., 2010). Secara keseluruhan, nilai $\mathrm{N}$ total pada setiap upaya pemulihan hutan rawa gambut memiliki kriteria sangat tinggi. Namun, sebagian besar $\mathrm{N}$ yang berada di gambut berada dalam bentuk organik sehingga ketersediaannya bagi tanaman tergolong rendah yang mengharuskan $\mathrm{N}$ melalui proses mineralisasi terlebih dahulu agar menjadi tersedia bagi tanaman (Stevenson, 1986; Hartatik et al., 2011; Agus et al., 2016). Perlakuan regenerasi alami berbeda nyata terhadap $\mathrm{N}$ dengan nilai tertinggi terdapat pada hutan sekunder sebesar 1,20 \% sedangkan nilai terendah terdapat pada regenerasi alami sebesar $1,10 \%$ (Tabel 2). Sifat asli $\mathrm{N}$ dalam gambut memiliki keragaman yang tinggi dan dipengaruhi oleh banyak proses seperti translokasi maupun volatilisasi, keragaman dan jumlah populasi vegetasi yang tumbuh di atasnya, serta kadar air dan kelembaban tanah (Steltzer dan Bowman, 


\section{Jurnal Tanah dan Sumberdaya Lahan Vol 8 No 1: 221-230, 2021 e-ISSN:2549-9793, doi: 10.21776/ub.jts1.2021.008.1.25}

1998; Bai et al., 2012). N total pada hutan sekunder lebih tinggi karena lebih tingginya kadar air dan kelembaban gambut pada lahan tersebut jika dibandingkan dengan dua lokasi lainnya. Pulunggono et al. (2019) melaporkan bahwa penurunan nilai $\mathrm{N}$ total pada suatu lahan salah satunya dipengaruhi oleh penurunan kadar air tanah pada lahan tersebut. Hal itu berkaitan dengan sifat dari unsur $\mathrm{N}$ yang mudah tervolatilisasi pada kondisi kadar air yang rendah.

Kondisi vegetasi yang berbeda antar ketiga lokasi berupa keanekaragaman dan jumlah populasi menjadi salah satu faktor lain adanya perbedaan nilai $\mathrm{N}$ total yang didapatkan. Tingginya nilai $\mathrm{N}$ total pada hutan sekunder diakibatkan oleh tingginya keragaman dan populasi vegetasi sehingga masukan bahan organik lebih banyak dibandingkan pada revegetasi dan regenerasi alami. Hal tersebut diakibatkan tidak adanya gangguan pengurangan jumlah populasi vegetasi pada hutan sekunder akibat dari kebakaran hutan yang terjadi sudah jauh lebih lama dibandingkan pada kedua lokasi lainnya. Steltzer dan Bowman (1998) melaporkan bahwa nilai $\mathrm{N}$ total sangat dipengaruhi oleh keanekaragaman dan jumlah dari masukan bahan organik karena perbedaan komposisi kimianya. Semakin banyak dan beragamnya komposisi vegetasi serta akan meningkatkan mineralisasi N. Hal ini yang menyebabkan rendahnya nilai $\mathrm{N}$ total pada regenerasi alami karena komposisi vegetasi yang sedikit sehingga proses mineralisasi $\mathrm{N}$ berjalan lambat karena jumlah masukan yaitu bahan organik sedikit.

\section{Phospor (P)}

$\mathrm{P}$ tersedia merupakan $\mathrm{P}$ yang terlarut dalam air dan dapat diserap oleh tanaman, sedangkan $\mathrm{P}$ total adalah kumulatif $\mathrm{P}$ tersedia dengan $\mathrm{P}$ yang belum diserap tanaman karena terfiksasi atau masih berada dalam bahan organik yang belum termineralisasi. Ketersediaan P dan daya simpan $\mathrm{P}$ yang rendah menjadi permasalahan hara pada gambut. Penyebab rendahnya daya simpan $\mathrm{P}$ pada gambut dikarena $\mathrm{P}$ diikat oleh senyawasenyawa organik dengan kekuatan ikatan yang lemah. Ion $\mathrm{P}$ yang terikat pada tapak jerapan mudah terlepas dan terbawa air lindian (Agus et al., 2016). Secara keseluruhan, nilai P pada seluruh upaya pemulihan hutan rawa gambut memiliki kriteria sangat rendah. Hal ini karena $\mathrm{pH}$ tanah pada daerah penelitian memiliki kriteria sangat masam. Menurut Rahmah et al. (2014) faktor yang dapat menghambat ketersediaan $\mathrm{P}$ dalam tanah disebabkan kegiatan organisme yang kurang maksimal, $\mathrm{pH}$ tanah yang relatif asam dan alkalis, serta jumlah dan dekomposisi bahan organik yang sedikit. Sebagian kadar P di dalam gambut berada dalam bentuk organik dan harus dimineralisasi sebelum menjadi tersedia bagi tanaman. Menurut Istomo (2006) bahwa P dalam tanah mineral didominan berasal dari pelapukan batuan sedangkan $\mathrm{P}$ dalam gambut berasal dari P organik.

Perlakuan hutan sekunder, revegetasi dan regenerasi alami berbeda nyata terhadap $\mathrm{P}$ tanah (total dan tersedia) dengan nilai tertinggi terdapat pada hutan sekunder sebesar $8,79 \mathrm{mg}$ $100 \mathrm{~g}^{-1}$ untuk $\mathrm{P}$ total dan 2,71 ppm P untuk P tersedia sedangkan nilai terendah terdapat pada regenerasi alami sebesar 3,92 mg $100 \mathrm{~g}^{-1}$ untuk P total dan 2,28 ppm P untuk P tersedia (Tabel 2). Hutan sekunder memiliki nilai $P$ tertinggi karena hutan sekunder terakhir terbakar pada tahun 1997 dengan gambut yang tidak tergenang sedangkan revegetasi dan regenerasi alami terakhir terbakar pada tahun 2015 dengan gambut yang masih tergenang pasca terbakar, hal ini menunjukkan semakin lama proses pemulihan pasca kebakaran maka kandungan $\mathrm{P}$ akan meningkat. Menurut Setiadi et al. (2016) gambut yang tidak tergenang setelah terbakar maka mikroorganisme akan aktif kembali untuk melakukukan dekomposisi sisa dari pembakaran.

\section{Kalium (K)}

Kalium merupakan satu-satunya kation monovalen yang esensial bagi tanaman karena perannya sebagai aktivator berbagai enzim dalam metabolisme karbohidrat dan protein serta membantu mengatur tekanan osmotik dan keseimbangan ion di dalam tanaman (Wiraatmaja, 2016). Secara keseluruhan, nilai K pada setiap upaya pemulihan hutan rawa gambut memiliki kriteria sangat rendah. Rendahnya nilai K karena daerah penelitian tergolong dalam tipe iklim tropis basah sehingga curah hujan tinggi sehingga menyebabkan $\mathrm{K}$ mudah hilang tercuci. 


\section{Jurnal Tanah dan Sumberdaya Lahan Vol 8 No 1: 221-230, 2021 e-ISSN:2549-9793, doi: 10.21776/ub.jts1.2021.008.1.25}

Hal tersebut sesuai dengan pendapat Hakim et al. (1986) bahwa $\mathrm{K}$ tanah sebagian besar berada dalam mineral tanah yang kurang tahan terhadap pengaruh air yang mengandung $\mathrm{CO}_{2}$ karena gambut memiliki kapasitas serapan $\mathrm{K}$ yang rendah dan stabilitas ikatan $\mathrm{K}$ dengan gambut yang rendah sehingga $\mathrm{K}$ mudah tercuci.

Perlakuan regenerasi alami berbeda nyata terhadap $\mathrm{K}$ dengan nilai tertinggi terdapat pada hutan sekunder sebesar 7,43 mg $100 \mathrm{~g}^{-1}$ sedangkan nilai terendah terdapat pada regenerasi alami sebesar $6,11 \mathrm{mg} 100 \mathrm{~g}^{-1}$ (Tabel 2). Tidak adanya upaya untuk penanaman jenis tanaman tertentu pada regenerasi alami mengakibatkan jumlah vegetasi yang lebih sedikit dibandingkan hutan sekunder dan revegetasi. Nilai $\mathrm{K}$ akan meningkat jika suatu lahan memiliki susunan vegetasi yang kompleks. Hal ini berkaitan dengan penelitian Safrizal et al. (2016) bahwa penyebab peningkatan nilai K- total pada hutan tanaman industri (HTI) diakibatkan oleh tumpukan seresah sisa tanaman seperti sisa daun dan ranting pada kawasan hutan tanaman indrustri (HTI). Sisa tanaman ini mengandung kalium yang dapat tersedia kembali di dalam tanah sehingga dapat dikatakan bahwa semakin banyak dan beragamnya vegetasi pada suatu lahan maka semakin banyak seresah yang dihasilkan dan apabila proses dekomposisi dan mineralisasi terus berjalan maka akan berpengaruh terhadap $\mathrm{K}$ di dalam tanah. Semakin banyak vegetasi pohon akan memengaruhi kerapatan akar sehingga berpotensi mengurangi terjadinya pencucian $\mathrm{K}$ sehingga resiko kehilangan $\mathrm{K}$ akan menurun. Hal ini yang menyebabkan rendahnya nilai $\mathrm{K}$ pada regenerasi alami karena komposisi vegetasi yang sedikit berpengaruh terhadap rendahnya kerapatan akar sehingga $\mathrm{K}$ lebih mudah hilang tercuci.

Tabel 2. Nitrogen, phospor dan kalium pada berbagai upaya pemulihan hutan.

\begin{tabular}{|c|c|c|c|c|c|c|c|}
\hline $\mathbf{P H}$ & $\mathbf{N}(\%)$ & $\mathbf{K r}$ & $\begin{array}{c}\text { P total } \\
\left(\mathrm{mg} 100 \mathrm{~g}^{-1}\right)\end{array}$ & $\begin{array}{l}\text { P tersedia } \\
(\mathrm{ppm})\end{array}$ & $\mathrm{Kr}$ & $\begin{array}{c}\mathrm{K} \\
\left(\mathrm{mg} 100 \mathrm{~g}^{-1}\right)\end{array}$ & $\mathrm{Kr}$ \\
\hline HS & $1,20 \mathrm{a}$ & ST & $8,79 \mathrm{a}$ & $2,71 \mathrm{a}$ & SR & $7,43 \mathrm{a}$ & SR \\
\hline $\mathrm{RB}$ & $1,18 \mathrm{a}$ & ST & $5,17 \mathrm{~b}$ & $2,53 \mathrm{~b}$ & SR & $7,26 \mathrm{a}$ & SR \\
\hline RA & $1,10 \mathrm{~b}$ & ST & $3,92 \mathrm{c}$ & $2,28 \mathrm{c}$ & SR & $6,11 \mathrm{~b}$ & SR \\
\hline$p=$ & $0,0023^{*}$ & & $<, 0001^{*}$ & $<, 0001 *$ & & $0,0264 *$ & \\
\hline
\end{tabular}

Keterangan: Angka yang diikuti dengan huruf yang beda pada kolom yang sama menyatakan beda nyata uji BNT 5\%. *(nyata). ST: sangat tinggi; SR: sangat rendah; PH: Pemulihan Hutan; HS: Hutan Sekunder; RB: Revegetasi; RA: Regenerasi alami, $\mathrm{Kr}=$ kriteria.

\section{Basa-basa dapat ditukar (K, Na, Ca, Mg)}

Kation basa tanah memiliki peranan penting dalam menunjang pertumbuhan tanaman. Menurut Mindawati et al. (2010), peran Mg bagi tanaman ialah sebagai struktur dasar klorofil, $\mathrm{Ca}$ sebagai pembentuk lamela tengah dan dinding sel sedangkan $\mathrm{K}$ sebagai kofaktor enzim. Secara keseluruhan, nilai K-dd, Na-dd, Ca-dd, Mg-dd pada seluruh upaya pemulihan hutan rawa gambut memiliki kriteria sangat rendah hingga rendah. Hal ini karena gambut pada daerah penelitian memiliki ketebalan lapisan 2-6 m (Rachmanadi, 2017). Semakin tebal gambut, maka basa-basa yang dikandungnya semakin rendah dan reaksi tanah menjadi semakin masam (Yondra et al., 2017). Perlakuan regenerasi alami berpengaruh nyata pada K-dd,
Na-dd, Ca-dd, Mg-dd dengan nilai tertinggi pada hutan sekunder $0,46 \mathrm{cmol}(+) \mathrm{kg}^{-1}$ untuk K-dd, $0,24 \mathrm{cmol}(+) \mathrm{kg}^{-1}$ untuk Na-dd $1,75 \mathrm{cmol}(+) \mathrm{kg}-$ ${ }^{1}$ untuk Ca-dd dan 1,84 $\mathrm{cmol}^{+}+\mathrm{kg}^{-1}$ untuk $\mathrm{Mg}$ dd (Tabel 3). Berdasarkan penelitian Setiadi $e t$ al., (2016) Desa Tumbang Nusa memiliki kriteria basa-basa dapat ditukar dari rendah sampai tinggi. Tingginya kandungan basa-basa dapat ditukar karena adanya perlakuan tertentu, sedangkan pada regenerasi alami tidak ada perlakuan tambahan seperti di hutan sekunder dan revegetasi yang terdapat berupa penanaman vegetasi. Kejenuhan basa berkaitan erat dengan $\mathrm{pH}$ dimana penurunan $\mathrm{pH}$ akan diikuti dengan penurunan kejenuhan basa (Hardjowigeno, 2010). Umumnya gambut memiliki $\mathrm{pH}$ yang tergolong sangat masam sehingga kation-kation basanya juga rendah. 
Jurnal Tanah dan Sumberdaya Lahan Vol 8 No 1: 221-230, 2021

e-ISSN:2549-9793, doi: 10.21776/ub.jts1.2021.008.1.25

Tabel 3. Basa-basa dapat ditukar (K-dd, Na-dd, Ca-dd, Mg-dd).

\begin{tabular}{|c|c|c|c|c|c|c|c|c|c|c|}
\hline PH & $\begin{array}{c}\text { K-dd } \\
\left(\mathrm{cmol} \mathrm{(+)}^{(+)}\right. \\
\left.\mathrm{kg}^{-1}\right)\end{array}$ & $\mathbf{K r}$ & $\begin{array}{c}\mathrm{Na}-\mathrm{dd} \\
(\mathrm{cmol}(+) \\
\left.\mathrm{kg}^{-1}\right)\end{array}$ & $\mathbf{K r}$ & $\begin{array}{c}\text { Ca-dd } \\
\left(\mathrm{cmol} \mathrm{(+)}^{(+)}\right. \\
\left.\mathrm{kg}^{-1}\right)\end{array}$ & $\mathrm{Kr}$ & $\begin{array}{c}\text { Mg-dd } \\
\left(\mathrm{cmol}^{(+)}\right) \\
\left.\mathrm{kg}^{-1}\right)\end{array}$ & $\mathbf{K r}$ & $\begin{array}{c}\text { Na-dd } \\
\left(\mathrm{cmol}^{2}\right. \\
\left.(+) \mathrm{kg}^{-1}\right) \\
\end{array}$ & $\mathbf{K r}$ \\
\hline $\mathrm{HS}$ & $0,46 \mathrm{a}$ & SR & $0,24 \mathrm{a}$ & SR & $1,75 \mathrm{a}$ & SR & $1,84 \mathrm{a}$ & $\mathrm{R}$ & $0,24 a$ & SR \\
\hline $\mathrm{RB}$ & $0,45 \mathrm{a}$ & SR & $0,20 \mathrm{~b}$ & SR & $1,38 \mathrm{~b}$ & SR & $1,71 \mathrm{ab}$ & $\mathrm{R}$ & $0,20 \mathrm{~b}$ & SR \\
\hline RA & $0,38 \mathrm{~b}$ & SR & $0,13 \mathrm{c}$ & SR & $0,65 \mathrm{c}$ & SR & $1,53 \mathrm{~b}$ & $\mathrm{R}$ & $0,13 \mathrm{c}$ & SR \\
\hline$p=$ & $0,01 *$ & & $<, 0001 *$ & & $<, 0001^{*}$ & & $0,0056 *$ & & $<, 0001 *$ & \\
\hline
\end{tabular}

Keterangan: Angka yang diikuti dengan huruf yang beda pada kolom yang sama menyatakan beda nyata uji BNT 5\%. *(nyata). SR: sangat rendah; PH: Pemulihan Hutan; HS: Hutan Sekunder; RB: Revegetasi; RA: Regenerasi alami.

\section{Kadar abu}

Kadar abu merupakan komposisi mineral yang dikandung oleh gambut yang diperoleh oleh gambut yang diperoleh dari hasil pembakaran tanah pada suhu lebih dari $600^{\circ} \mathrm{C}$ yang bertujuan untuk mengetahui seberapa besar kandungan bahan organik dan bahan mineral yang ada pada tanah (Salma et al., 2019). Semakin tinggi kadar abu maka semakin tinggi mineral yang terkandung pada gambut (Noor, 2001). Perlakuan hutan sekunder berbeda nyata terhadap kadar abu serta memiliki nilai tertinggi sebesar 9,49\%, sedangkan pada revegetasi dan regenerasi alami memiliki nilai yang tidak berbeda jauh antar keduanya (Tabel 4). Hutan sekunder memiliki nilai kadar abu tertinggi karena memiliki tingkat kematangan gambut tertinggi ditunjukkan pada proses pasca kebakaran yang telah terjadi lebih dahulu dibandingkan dengan revegetasi dan regenerasi alami.

Tabel 4. Kadar abu dan kadar air

\begin{tabular}{ccc}
\hline PH & Kadar Abu \% & Kadar Air (\%) \\
\hline HS & $9,49 \mathrm{a}$ & $42,78 \mathrm{a}$ \\
RB & $7,02 \mathrm{~b}$ & $30,69 \mathrm{~b}$ \\
RA & $7,01 \mathrm{~b}$ & $30,68 \mathrm{~b}$ \\
\hline p $=$ & $0,06^{*}$ & $<, 0001^{*}$ \\
\hline
\end{tabular}

Keterangan: Angka yang diikuti dengan huruf yang beda pada kolom yang sama menyatakan beda nyata uji BNT 5\%. *(nyata). PH: Pemulihan Hutan; HS: Hutan Sekunder; RB: Revegetasi; RA: Regenerasi alami.

Tingkat kadar abu memiliki hubungan dengan tingkat kematangan gambut. Agus et al, (2016) melaporkan bahwa gambut mentah (fibrik) memiliki kadar abu 3,09\%, gambut hemik memiliki kadar abu 8,04\% dan gambut matang (saprik) memiliki kadar abu 12,04\%. Berdasarkan hal tersebut, dapat dikatakan bahwa semakin matang gambut, maka semakin tinggi pula nilai kadar abunya.

\section{Kadar air}

Gambut memiliki kapasitas mengikat atau memegang air yang relatif sangat tinggi (Susandi et al., 2015). Komposisi bahan organik yang dominan menyebabkan gambut mampu menyerap air dalam jumlah yang relatif tinggi, sehingga kemampuan menyerap dan menyimpan air jauh lebih tinggi dibanding tanah mineral. Namun, karena air sebagian besar berada dalam pori makro, maka begitu gambut didrainase maka air menjadi cepat sekali hilang (Dariah et al., 2018). Perlakuan hutan sekunder berbeda nyata terhadap kadar air serta memiliki nilai tertinggi sebesar $42,78 \%$, sedangkan pada revegetasi dan regenerasi alami memiliki nilai yang tidak berbeda jauh antar keduanya (Tabel 4). Pada lokasi regenerasi dan revegetasi telah mengalami proses kekeringan hebat akibat kebakaran lahan pada tahun 2015 sehingga akan memengaruhi kemampuan gambut dalam memegang air. Keadaan ini disebut dengan kering tak balik (irreversible drying) yakni kemampuan gambut dalam menyimpan, memegang, dan melepas air (Noor, 2001). Kemampuan gambut dalam menjerap dan memegang air akan pulih seiring dengan proses pemulihan gambut namun dalam waktu yang sangat lama. Hal tersebut yang menyebabkan hutan sekunder memiliki nilai kadar air tertinggi karena kebakaran yang terjadi lebih dahulu dibandingkan dengan revegetasi dan regenerasi alami. 


\section{Jurnal Tanah dan Sumberdaya Lahan Vol 8 No 1: 221-230, 2021 e-ISSN:2549-9793, doi: 10.21776/ub.jts1.2021.008.1.25}

\section{Keragaman lokasi}

Keragaman lokasi merupakan metode yang digunakan untuk mengetahui pengaruh acak yakni jumlah dan sebaran (sub plot dan titik sampel) dapat menimbulkan efek pada perlakuan secara terpisah. Hal ini dilakukan karena gambut memiliki kondisi yang berbeda yakni ketebalan lapisan gambut yang bervariasi dan perbedaan jumlah vegetasi pada masingmasing lokasi. Setelah dilakukan pengujian keragaman pada masing-masing sifat kimia, dengan tingkat kepercayaan sebesar 95\% terdapat cukup bukti bahwa keragaman pada efek acak sub plot tidak berpengaruh pada semua sifat kimia (Tabel 5). Keragaman pada efek acak titik sampel hanya berpengaruh terhadap sifat kimia $\mathrm{pH} \quad \mathrm{H}_{2} \mathrm{O}$ serta tidak berpengaruh terhadap sifat kimia lainnya. Hal ini menunjukkan bahwa jumlah dan sebaran sub plot dan titik sampel tidak memengaruhi perbedaan sifat kimia gambut, tetapi yang lebih menentukan perbedaan sifat kimia gambut adalah teknik pemulihan hutan rawa gambut.

Tabel 5. Nilai F hitung dan F tabel pada sub plot dan titik sampel.

\begin{tabular}{lcccc}
\hline \multirow{2}{*}{ Variabel Pengamatan } & \multicolumn{2}{c}{ Sub Plot } & \multicolumn{2}{c}{ Titik Sampel } \\
\cline { 2 - 5 } & F hitung & F tabel & F hitung & F tabel \\
\hline $\mathrm{pH} \mathrm{H} \mathrm{H}_{2} \mathrm{O}$ & 0.710 & 2.839 & 2.161 & 1.904 \\
$\mathrm{pH} \mathrm{KCl}$ & 0.214 & 2.839 & 0.929 & 1.904 \\
$\mathrm{C}$-organik & 0.853 & 2.839 & 1.102 & 1.904 \\
$\mathrm{KTK}$ & 0.605 & 2.839 & 0.346 & 1.904 \\
$\mathrm{~N}$ & 0.114 & 2.839 & 0.058 & 1.904 \\
$\mathrm{P}$ total & 0.526 & 2.839 & 0.307 & 1.904 \\
$\mathrm{P}$ tersedia & 0.079 & 2.839 & 0.038 & 1.904 \\
$\mathrm{~K}$ & 0.584 & 2.839 & 1.420 & 1.904 \\
$\mathrm{~K}$-dd & 0.874 & 2.839 & 0.759 & 1.904 \\
$\mathrm{Na}$-dd & 0.241 & 2.839 & 0.172 & 1.904 \\
$\mathrm{Ca}-d d$ & 0.1174 & 2.839 & 0.2105 & 1.904 \\
$\mathrm{Mg}$-dd & 0.3345 & 2.839 & 0.564 & 1.904 \\
Kadar abu & 0.422 & 2.839 & 0.804 & 1.904 \\
Kadar air & 0.114 & 2.839 & 0.058 & 1.904 \\
\hline
\end{tabular}

\section{Kesimpulan}

Upaya pemulihan KHDTK dengan menjadikan hutan sekunder merupakan teknik pemulihan hutan rawa gambut terbaik dibandingkan dengan revegetasi dan regenerasi alami. Jumlah dan sebaran sub plot dan titik sampel tidak mempengaruhi perbedaan sifat kimia gambut. Teknik pemulihan hutan rawa gambut menentukan perbedaan sifat kimia gambut.

\section{Ucapan Terima Kasih}

Penulis mengucapkan terima kasih kepada Balai Penelitian dan Pengembangan Lingkungan Hidup dan Kehutanan, Banjarbaru yang telah mengizinkan untuk melakukan penelitian di KHDTK Tumbang Nusa. Ucapan terimakasih juga disampaikan kepada proyek penelitian kerjasama ACIAR FST/2016/114 atas dukungannya.

\section{Daftar Pustaka}

Agus, F., Markus, A., Ali, J. dan Masganti. 2016. Lahan Gambut Indonesia. G Conservation Cervice. FAO Land and Water Development Division. FAO, Rome.

Aristio, A., Wardati, dan Wawan. 2017. Sifat kimia tanah dan pertumbuhan tanaman karet (Havea brasiliensis Muell. Arg) pada tanah gambut yang ditumbuhi dan tidak ditumbuhi Mucuna bracteata. JOM Faperta Universitas Riau 4(1): 7-12.

Bai, J., Gao, H., Hiao, R., Wang, J. dan Huang, C. 2012. A review of soil nitrogen mineralization as affected by water and salt in coastal wetlands: issues and methods. Clean-Soil, Air, Water 40(10): 1099-1105.

Boehm, H.D.V. and Siegert, F. 2001. Ecological Impact of the One Million Hectare Rice Project in Central Kalimantan, Indonesia, Using Remote 


\section{Jurnal Tanah dan Sumberdaya Lahan Vol 8 No 1: 221-230, 2021 e-ISSN:2549-9793, doi: 10.21776/ub.jts1.2021.008.1.25}

Sensing and GIS. Paper presented at the $22^{\text {nd }}$ Asian Conference on Remote Sensing.

Dariah, Ai., Maftuah, E. dan Maswar. 2018. Panduan Pengelolaan Berkelanjutan Lahan Gambut Terdegradasi: Karakteristik Lahan Gambut. Balai Penelitian Tanah. Bogor

Driessen, P.M. dan H. Suhardjo. 1976. On The Defective Grain Formation of Sawah Rice on Peat. Soil Res. Inst. Bull. 3: 20 - 44. Bogor.

Hakim N, Yusuf N, Am Lubis, Sutopo GN, M Amin D, Go BH, HH Bailley. 1986. Dasar-dasar Ilmu Tanah. Universitas Lampung. Lampung

Hardjowigeno, S. 2010. Ilmu Tanah. Jakarta. Akademika Pressindo

Hartatik, W., Subiksa, I.G.M. dan Dariah, Ai. 2011. Sifat Kimia dan Fisik Tanah Gambut pada Pengelolaan Lahan Gambut Berkelanjutan. Balai Penelitian Tanah. Bogor

Istomo. 2006. Evaluasi dan Penyesuaian Sistem Silvikultur Hutan Rawa Gambut, Khususnya Jenis Ramin (Gonystylus bancanus (Miq.) Kurz.) di Indonesia. Prosiding Workshop Nasional Alternatif Kebijakan dalam Pelestarian dan Pemanfaatan Ramin. Bogor, 22 Februari 2006. Pusat Penelitian dan Pengembangan Hutan dan Konservasi Alam bekerjasama dengan ITTO PPD 87/03.

Kementerian Lingkungan Hidup dan Kehutanan. 2015. Indonesian National Carbon Accounting System Kalimantan System. http://incas.menlhk.go.id/id/data/centralkalimantan.

Kurnain, A., Notohadikusumo, T., Radjagukguk, B. dan Hastuti, S. 2001. The Stage of Decomposition of Tropical Peat Soil Under Cultivated and Fire Damage Peatland. Pp.168178. Proceeding on Peatlands for People: Natural Resources Function and Sustainable Management.

Marlina, S. 2017. Pengelolaan ekosistem gambut pasca kebakaran lahan gambut di Provinsi Kalimantan Tengah. Media Ilmiah Teknik Lingkungan 2(1): 26-30.

Miller, M.H. and Donahue, R.L. 1990. Soils an Introduction to Soils and Plant Growth. Prentice Hall Englewood Cliffs. New Jersey.

Mindawati, N., Indrawan, A., Mansur, I. dan Rusdiana, O. 2010. Analisis sifat-sifat tanah di bawah tegakan Eucaplitus urograndis. Jurnal Tanaman Hutan 3(1): 13-22

Noor, M. 2001. Pertanian Lahan Gambut: Potensi dan Kendala. Kanisius. Yogyakarta

Nurida, N.L. dan Jubaedah. 2014. Teknologi Peningkatan Cadangan Karbon Lahan Kering dan Potensinya pada Skala Nasional. Badan
Penelitian dan Pengembangan Pertanian. Kementerian Pertanian

Pulunggono, H.N., Anwar, S., Mulyanto, B. dan Sabiham, S. 2019. Dinamika hara pada lahan gambut dengan penggunaan lahan kebun kelapa sawit, semak dan hutan sekunder. Natural Resources and Environmental Management 9(3): 692-699.

Rachmanadi, D. 2017. Percepatan Suksesi Alami Hutan Rawa Gambut Tropika Pasca Degradasi: Seleksi dan Uji Faktor-faktor Lingkungan. [Disertasi] Program Pasca Sarjana Program Studi Ilmu Kehutanan. Universitas Gadjah Mada. Yogyakarta

Rahmah, S., Yusran, dan Husain, U. 2014. Sifat kimia tanah pada berbagai tipe penggunaan lahan di Desa Bobo Kecamatan Palolo Kabupaten Sigi. Warta Rimba 2(1): 88-85.

Rusdiana, O. dan Lubis, R.S. 2012. Pendugaan korelasi antara karakteristik tanah terhadap cadangan karbon (carbon stock) pada hutan sekunder. Jurnal Silvikultur Tropika 3(1):14-21

Safrizal, O. dan Robbana S. 2016. Analisis sifat kimia gambut pada tiga tipe penggunaan lahan di Desa Pangkalan Panduk Kecamatan Kerumutan Kabupaten Pelalawan. Jurnal Agroekoteknologi 7: 87-92.

Salma, J.F., Prijono, S. dan Maswar. 2019. Pengaruh pemupukan pada lahan gambut terhadap karakteristik tanah, emisi $\mathrm{CO}_{2}$, dan produktivitas tanaman karet. Jurnal Tanah dan Sumberdaya Lahan 6(1):1145-1156.

Sembiring, I.S., Wawan dan Amrul, K. 2015. Sifat kimia tanah Dystrudepts dan pertumbuhan akar tanaman kelapa sawit (Elaeis Guineensis Jacq.) yang di aplikasi mulsa organik Mucuna bracteata. JOM Faperta 2(2): 15-20.

Setiadi, I.C., Yulianti, N. dan Adji, F.F., 2016. Evaluasi sifat kimia dan fisik gambut dari beberapa lokasi di Blok C eks-PLG Kalimantan Tengah. Jurnal Agri Peat 17: 31-36.

Setiawan, H.K. 1991. Akibat Pemampatan Atas Sifat Sifat Hidrologi Gambut Sehubungan dengan Tingkat Perombakan. Tesis. Departemen Ilmu Tanah. Fakultas Pertanian. Universitas Gadjah Mada. Yogyakarta

Steltzer, H. dan Bowman, W.D. 1998. Differential influence of plant species on soil nitrogen transformations within moist meadow alpine tundra. Ecosystems 1: 464-474.

Stevenson, F.J. 1986. Cycles of Soil Carbon, Nitrogen, Phosphorus, Sulfur and Micronutrients. John Willey \& Sons Inc. New York.

Sudaryono. 2009. Tingkat kesuburan tanah ultisol pada lahan pertambangan batubara Sangatta, 


\section{Jurnal Tanah dan Sumberdaya Lahan Vol 8 No 1: 221-230, 2021}

e-ISSN:2549-9793, doi: 10.21776/ub.jts1.2021.008.1.25

Kalimantan Timur. Jurnal Teknik Lingkungan 10(3): 21-28.

Sulistiyanto, Y., Rieley, J.O. dan Limin, S.H. 2005. Laju dekomposisi dan pelepasan hara dari seresah pada dua sub-tipe hutan rawa gambut di Kalimantan Tengah. Jurnal Manajemen Hutan Tropika 1(2):1-14.

Susandi, Oksana dan Ahmad, T.A. 2015. Analisis sifat fisika tanah gambut pada hutan gambut di Kecamatan Tambang Kabupaten Kampar Provinsi Riau. Jurnal Agroekoteknologi 5(2): 2328.
Winarso, S. 2005. Kesuburan Tanah: Dasar Kesehatan dan Kualitas Tanah. Gava Media. Yogyakarta.

Wiraatmaja, I.W. 2016. Pergerakan Hara Mineral dalam Tanaman. Program Studi Agroekoteknologi. Fakultas Pertanian Universitas Udayana

Yondra, N. dan Wawan. 2017. Kajian sifat kimia lahan gambut pada berbagai landuse. AGRIC Jurnal Ilmu Pertanian 29(2): 103-112. 